\title{
Følelser på museum
}

\author{
Martin Brandt Djupdrat** og Henrik Hatt*
}

\begin{abstract}
This article describes a series of experimental trials regarding the role of feelings in a museum context. These trials were carried out at Moesgard Museum in Denmark, and consisted of a series of additions to the museum's permanent exhibitions. The trial set-ups were designed to provide visitors with the best possible opportunities for emotionally relating to the exhibits in question. Observations as well as qualitative interviews were used to study which effects the trial set-ups had, seen in relation to the permanent exhibition, and whether it was possible to trace any effect regarding how the visitors experienced the rest of the exhibition.

The trials demonstrated that even very small efforts focused on creating an emotional response among visitors had the potential to create a greatly increased sense of relevance, empathy and interest in relation to the exhibits. It was also shown that space, and the sequential layout of space, also had significant potential for creating a sense of emotional empathy among visitors.
\end{abstract}

Key words: Affective learning, feelings, museum presentation and interpretation, empathy, creating relevance, Moesgård Museum, user survey.

Hvordan sikrer museerne de besøgende en god oplevelse?

Hvordan sikrer museerne, at de overhovedet får en oplevelse?

Og hvad konstituerer egentlig en oplevelse for slet ikke at tale om en god oplevelse?

Med udgangspunkt i Dierking og Falks interactive experience model kan museumsoplevelsen beskrives som en interaktion mellem den personlige kontekst, den sociale kontekst og det fysiske rum. ${ }^{1}$ Hos Falk og Dierking er den personlige kontekst forstået som den personlige bagage og erfaring den enkelte museumsgæst medbringer til museet. Eksplicit i denne betragtning ligger der, at der ikke er en fælles reference de museumsbesøgende imellem. Modsat Falk og Dierking vil vi dog i denne artikel forsøgsvis tage vores udgangspunkt $i$, at en sådan fælles referenceramme muligvis alligevel eksisterer.

Den fællesnævner vi har valgt at tage udgangspunkt i er dog ikke en fælles erindring, men derimod identifikation og menneskelige følelser som sorg, glæde og medfølelse - følelser som alle mennesker kan blive konfronteret med ved bestemte begivenheder og omstændigheder.

Ved at skabe forudsætningerne for og spille på disse følelser i museumsudstillinger vil de besøgende måske i højere grad opleve udstil- 
54 lingernes emner som relevante at engagere sig i - både på kortere og længere sigt.

Ud fra denne hypotese har Moesgård Museum i Århus ${ }^{2}$ og NIRAS Konsulenterne ${ }^{3}$ udført en række eksperimenter, der netop fokuserer på at skabe emotionelle oplevelser gennem museumsudstillinger.

Eksperimenterne blev udført i sammenhæng med tre udstillinger på Moesgård Museum i november 2008. Det første eksperiment foregik ved skeletterne fra Tybrind Vig, der er placeret i museets udstilling om stenalderen, det andet eksperiment foregik ved Grauballemanden, og det tredje eksperiment foregik i udstillingen om jernalderens våbenofring i Illerup Ådal ved en montre, der viser personlige ejendele fra faldne soldater i slaget.

Der blev lavet to typer forsøgsopstillinger. Den ene type opstilling forsøgte at appellere til de besøgende følelser gennem "fortidens stemme", hvor de besøgende blev konfronteret med det fortidige menneskes tanker og følelser. Den anden type opstilling spillede på en direkte sammenstilling mellem nutidige og fortidige menneskers oplevelser og følelser. Målet for alle forsøgsopstillingerne var således at finde links eller måder, hvorpå den besøgende, gennem en følelsesmæssig reaktion på det udstillede, bedre kunne relatere sig til emnet.

Eksperimenterne er lavet for at indsamle viden om brugen af affektive virkemidler i formidling. For Moesgård Museum er undersøgelsen også en del af det forarbejde museet har i forbindelse med, at museet skal flytte over i nye rammer i 2013. Ved at alle udstillingerne skal flyttes, er der en mulighed for at gentænke hele museet og den kulturhistoriske udstillings funktion og brug af virkemidler - heriblandt de virkemidler der arbejder med følelser hos de besøgende.

\section{MED DØDEN TIL FØLELSE}

Udgangspunktet for eksperimentet er hypotesen om, at vi som mennesker er bedre i stand til at relatere os til fortidens mennesker og sætte os ind i deres livsverden, hvis vi følelsesmæssigt berøres. Dette er den samme psykologiske proces, som når vi fordyber os i en gribende roman eller film og på godt og ondt føler med helten eller heltinden. Denne følelse kan vi ligeledes få, når vi tager på f.eks. forhistorisk museum og ser de genstande fortidens mennesker har efterladt sig. Til forskel fra de bøger og film der bygger på fiktion, kan museumsoplevelsen have en ekstra dimension, der kan styrke den følelsesmæssige identifikation, nemlig når museet fortæller om personer der har levet eller begivenheder der har fundet sted.

En begivenhed, som alle mennesker, før eller siden, skal forholde sig til, er døden. Døden og afdøde personer er samtidigt allestedsnærværende på mange museer. Nogle gange $\mathrm{i}$ meget konkret form - som ved udstillingen af Grauballemanden på Moesgård Museum. Andre gange indirekte gennem objekter, som har tilhørt afdøde mennesker. Døden vækker særlige følelser i de fleste af os; følelser som museer bevidst kan vælge at spille på og forstærke for herved at skabe en større indlevelse og engagement hos de besøgende. Dette var i hvert fald tesen, som skulle testes igennem tre forskellige udstillinger på Moesgård Museum, som alle har en tilknytning til døden som tema.

For at appellere til nutidige menneskers følelser er man nødt til at benytte virkemidler, som kan finde vej til det moderne menneskes følelsesregister. Vi havde derfor i eksperimentet omkring de tre forsøgsopstillinger opsat ekstra installationer, baseret på digitale billeder, moderne populær musik og Sean Conne- 
ry's genkendelige og associerende stemme. Ved at tilføje disse forholdsvis simple installationer kunne vi undersøge, hvilken betydning disse ekstra elementer havde for de besøgendes oplevelse af museumsbesøget og for deres forståelse af de enkelte udstillinger.

\section{Metode: Flere indsamlingsmetoder ER NØDVENDIGE!}

For at sikre at vi i eksperimentet fik så mange oplysninger som muligt om de besøgendes oplevelse af udstillingerne, både med og uden forsøgsinstallationerne, brugte vi både observationsstudier og efterfølgende korte, kvalitative interviews. Ved at notere personlige karakteristika ved de besøgende var det muligt at sammenligne de besøgendes opførsel i udstillingerne med deres efterfølgende udsagn.

De besøgende vidste ikke, at de blev observeret under besøget. På vej ud af museet blev de dog oplyst om eksperimentet og spurgt om de havde lyst til at blive interviewet om deres oplevelse på museet og i særdeleshed ved forsøgsopstillingerne.

I alt bestod materialet af 307 publikumsobservationer og 63 interviews gennemført over tre søndage i november 2009.

Det viste sig i de efterfølgende dataanalyser, at der var stor forskel på, hvordan de besøgende opførte sig i udstillingerne, og måden de senere italesatte deres oplevelse, altså hvad de sagde de gjorde, og hvad de så reelt havde gjort. For eksempel var der observationer af, at de genstande gæsterne brugte længst tid på eller snakkede mest om, mens de opholdt sig ved selve udstillingerne, i det efterfølgende interview ikke blev fremhævet som noget særligt. Dertil havde de fleste en oplevelse af at have opholdt sig meget længere tid ved de enkelte udstillinger end de reelt havde. Dette understreger vigtigheden af at kombinere flere dataindsamlingsmetoder, når et emne som oplevelser og følelser skal belyses.

\section{FORSøGET VED UDSTILLINGEN TYBRIND VIG PIGEN OG SPÆDBARNET}

Ved Tybrind Vig blev der ved en marinarkæologisk udgravning fundet skelettet af en ung pige, der var begravet med et spædbarn liggende på brystet. En mulig tolkning er, at der er tale om en mor og hendes barn.

Skeletterne, der er dateret til ca. $4.700 \mathrm{f}$. Kr., er præsenteret i gulvhøjde, og er det første man møder ved indgangen til stenalderudstillingen. Selve udstillingen og herunder fremstillingen af fundene fra Tybrind Vig er fra 1984. På en væg til venstre for fundet er der en kort nøgtern beskrivelse af den sparsomme viden, man har omkring fundet.

Tilrettelæggernes idé var, at udstillingen skulle vise de fortidige mennesker af kød og blod bag genstandene, og at opstillingerne skulle sende et signal til de besøgende om, at nutidens mennesker kan spejle sig i mennesker til alle tider. ${ }^{4}$ For at illustrere dette var der ved skeletterne fra Tybrind Vig præsenteret en tegning af en pige, som lige så vel kunne være fra i dag.

Da forventningerne til formidling og oplevelser har ændret sig meget fra 1984 til 2008, er det svært at sige, hvordan opstillingen oprindeligt påvirkede de besøgende. Vores eksperiment viste dog, at meget få besøgende stoppede op ved Tybrind Vig pigen. Dette kan muligvis skyldes, at montren er placeret lige ved indgangen til museet, og mange besøgende derfor overser den. Observationerne viste, at børn lagde mærke til skeletterne og trak deres forældre tilbage dertil - sandsynligvis fordi fundet er placeret i børnehøjde. 
Martin Brandt DJupdrat og Henrik Hatt

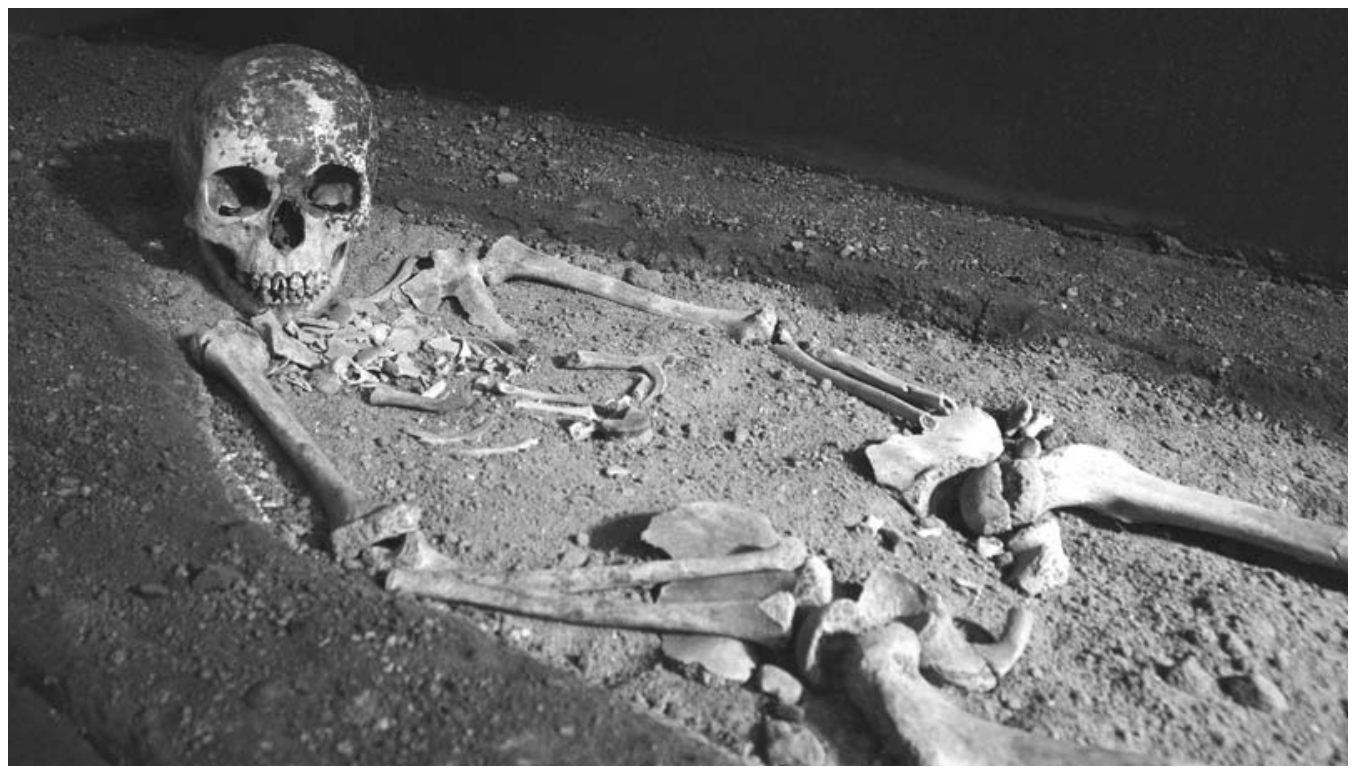

Fig. 1. Tybrind Vig pigen med spadbarn liggende på brystet. Forsøgsopstillingerne prasenterede på forskellig vis den menneskelige tragedie bag fundet. Foto: Moesgård Museum.

En besøgende gav denne forklaring på, hvorfor han ikke stoppede op ved Tybrind Vig pigen:

Vi ville lige lidt væk - finde vores eget rum.

Som denne besøgende hentyder til var det fleres oplevelse, at der er for meget trafik og uro ved indgangen til museet. Men udsagnet kan også ses som et udtryk for et ønske om at finde et mere privat fysisk og mentalt rum i museet, hvor det er muligt at opleve og reflektere for sig selv eller sammen med den gruppe man er kommet sammen med.

Ved Tybrind Vig pigen valgte vi at teste to følelsesfremmende virkemidler, der blev afprøvet hver for sig.

Det ene forsøg bestod af visning af en sekvens af sort-hvide fotos af unge mødre i tætte moderlige situationer med deres spædbarn. Formålet med dette foto set-up var at appellere til især kvindelige besøgendes medfølelse overfor Tybrind Vig pigen og spædbarnet, og herved gøre det nemmere for dem at relatere sig til Tybrind Vig pigen, og til den hændelse, der skete for flere tusind år siden.

Flere personer havde svært ved at forholde sig til denne kobling af skeletterne og de moderne æstetiske fotos. Umiddelbart fandt nogle personer opstillingen lidt søgt, mens andre diskuterede hvorfor billederne mon var sat op. Formålet var altså ikke direkte forståeligt og appellerede måske derfor til en intellektuel refleksion frem for at fremkalde følelser. En af årsagerne til denne reception kan måske igen skyldes placeringen i museet, hvor folk ikke er mentalt forberedt på den type oplevelser, der spiller på følelser. En vigtig pointe er derfor, at 
folk i højere grad skal forberedes til bestemte følelser.

Det andet forsøg var en lyttestation med høretelefoner, hvori en mandsstemme (som i forestillingens verden kunne have været faderen til barnet) med baggrundsmusik fortalte om hans desperate situation og sine følelser efter at have lagt sin udkårne og deres nyfødte barn i graven. Hensigten med denne opstilling var at teste en indfaldsvinkel, som kunne appellere til mænds følelsesliv.

Den tydeligste respons fik vi ved denne opstilling En kvindelig besøgende, der halvandet år tidligere havde besøgt stenalderudstillingen og dengang fandt den kedelig og gammeldags, fortalte:

Jeg havde forventet at jeg syntes, det var kedeligt, fordi jeg var her for halvandet år siden, og der var det pi-

Fig. 2. En serie affotos med unge modre og deres spadbørn skulle gøre det lettere at relatere sig til Tybrind Vig pigen. Foto: Lana K. Shutterstock.

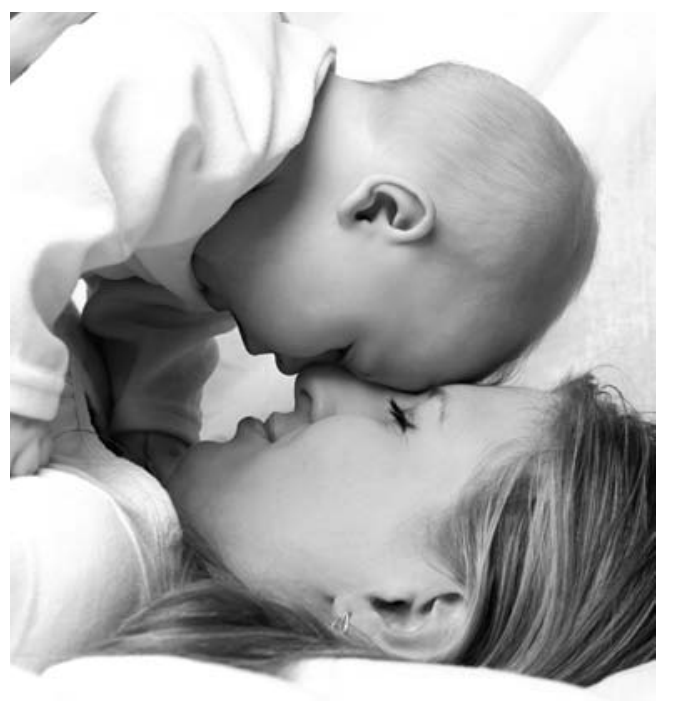

lespids på pilespids, men min oplevelse i dag var bedre.

Den personlige følelsesladede historie havde muligvis bidraget til helt at ændre hendes syn på og oplevelse af nøjagtig den samme udstilling. Hun gav nu udtryk for, at hun læste de fleste tekster i udstillingen. Denne reaktion kan muligvis tolkes som et resultat af, at det følelsesmæssige engagement har igangsat en interesse, som førte til en udvidet læringsproces. Som hun selv fortolker det:

Det er noget af det, som jeg kalder kulturformidling, hvor du får en historie [...] Man kan jo ikke lade være med at føle med den pige, ellers så var man da mærkelig.

\section{EKSPERIMENTET VED GRAubALLEMANDEN}

Grauballemanden er Moesgård Museums største trækplaster. En nyopstilling af ham sammen med en ny tilhørende udstilling blev gennemført i 2003. I denne opstilling ligger Grauballemanden alene i mørke omgivelser i et nedsænket rum, der repræsenterer mosen, som han blev fundet i. Over rummet findes udstillingen som fortæller historien om fundet og de videnskabelige resultater. Herfra kan man desuden se ned til ham gennem et hul i gulvet. I udstillingen kører et loop med baggrundslyde i form af vindklokker e.l., der skal stimulere en fortættet og lidt uhyggelig stemning af "offermosen".

Hensigten med denne nyopstilling var dels at præsentere den nye viden, man havde fået om ham ved de seneste undersøgelser, dels skulle selve præsentationen af Grauballemanden appellere til en fascination af ham som et fysisk menneske. Det skulle endvidere være muligt for de besøgende at sætte sig forskellige 
Martin Brandt DJupdret og HenRIK Hatt

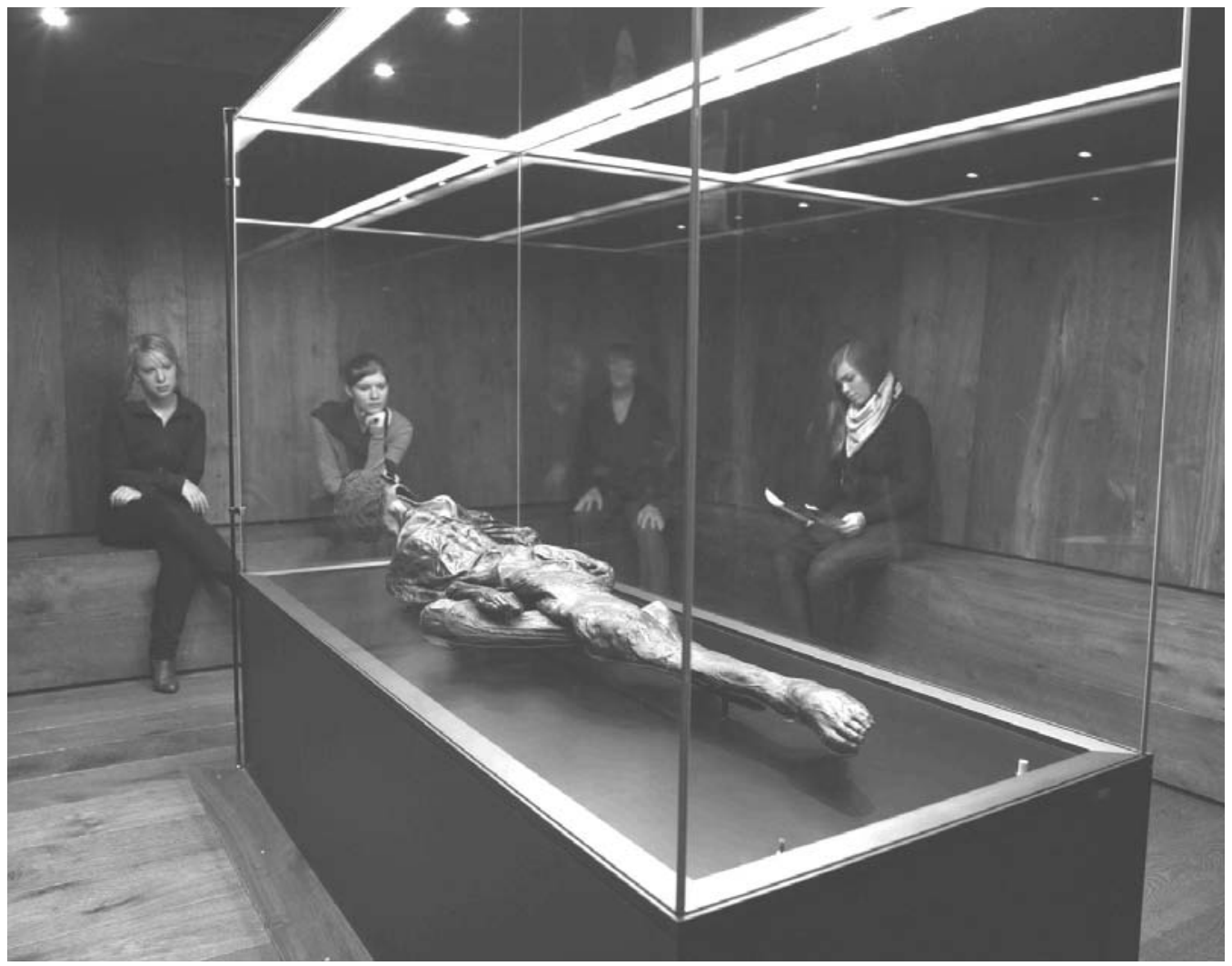

Fig. 3. De besøgendes brug af udstillingen af Grauballemanden andredes ved at tilfoje stemningsfuldt melodisk musik. Foto: Torben Mors for Roblon.

steder rundt om Grauballemanden og i en meditativ tilstand skabe tanker om ham og den tid han levede i, uden at blive forstyrret. ${ }^{5}$

Grauballemanden har - i kraft af sin enestående bevaring - et helt specielt potentiale til at appellere til følelser og en forståelse af fortidige menneskers lighed med nutidens. I forsøgsopstillingen forsøgte vi at udnytte dette potentiale ved at spille et stykke musik, hvor Sean Connery reciterer testen i Beatles-sangen "In My Life" - en tekst hvor en mand beskriver den betydning mennesker og steder han har mødt i sit liv har haft. Musikken i baggrunden af Sean Connerys stemme er en klassisk udgave af Beatles-melodien. Nummeret var bevidst valgt ud fra Sean Connerys fængslende stemme, der reflekterede over et levet liv samt at det var et stykke melodisk musik, der havde et melankolsk anslag. Vi ville også gerne have, at de besøgende fandt musikken behagelig, hvilket denne version af sangen kan karakteriseres som. Tanken med installationen var, at Sean Connerys stemme skulle forankres i Grauballemanden og få folk til indirekte at 
opfatte det som Grauballemandens egen stemme eller i hvert fald skabe et link mellem de tilbageskuende melankolske følelser som teksten og musikken afspejler og Grauballemandens levede liv.

Den tydeligst observerede forskel mellem vores nye installation kontra den oprindelige opstilling var, at en del besøgende nu satte sig nede i rummet. Det var der ingen besøgende som gjorde, når musikken ikke var der. Som én besøgende fortalte:

Jeg synes det var meget hyggeligere at sidde og kigge på ham i dag. Normalt plejer vi faktisk ikke at sætte os derned.

Igennem interviewene viste der sig endvidere, at gæsterne gjorde sig forskellige tanker under besøget. Ingen gav dog udtryk for, at de havde hørt efter teksten i musikken. De besøgende, som havde oplevet musikken, reflekterede over eksistentielle emner som krop, sjæl, indlevelse, døden og over at miste slægtninge. Flere gav udtryk for, at oplevelsen nede ved Grauballemanden fik dem til at danne billeder i hovedet og leve sig ind $\mathrm{i}$, hvordan fortidige mennesker har haft det. Som disse besøgende fortalte:

Musikken gjorde det mere fængslende og mere fangede oplevelse af det - mere stemningsfyldt på en måde. Det sætter i hvert fald nogle ting i gang.

Mine tanker var, at han bare er en krop nu, hans sjæl er væk.

Inde i mit hoved danner jeg mig et billede af hvordan de havde det. Det fik mig til at føle, hvordan de levede før.

Refleksionerne hos de besøgende, der besøgte Grauballemanden uden installationen, havde helt andre typer overvejelser og refleksioner, der var af mere rationel art som for eksempel om han havde tøj på, eller stolthed over at vi har verdens aldste mand herhjemme. Eller som en anden besøgende fortalte:

Jeg lagde mærke til, at under konserveringen er hans venstre ben brækket, det er måske derfor, at der ikke er så meget lys på!

Overraskende nok gav forsøgsopstillingen ikke anledning til, at de besøgende $\mathrm{i}$ gennemsnit brugte meget mere tid hos Grauballemanden (hhv. 1,63 minutter med musik og 1,54 minutter uden musik). Men oplevelsen havde tilsyneladende en anden og umiddelbart mere følelsesbetonet karakter, når de besøgende blev konfronteret med musikken. Mange af de besøgende fortalte, at de tidligere havde besøgt udstillingen, men at de med musikken følte sig mere behageligt til mode end ellers og oplevede, at de kunne bruge rummet til at reflektere i. Det blev måske i højere grad et refleksivt rum?

\section{EKSPERIMENTET I ILLERUP ÅdAL UDSTIL- LINGEN}

Illerup Ådal er Moesgård Museums udstilling om et fantastisk våbenofferfund fra jernalderen. Udstillingen er fra 2003 og er en meget æstetisk gennemført udstilling. Ud over den æstetiske vinkel er en af de primære formidlingsmæssige prioriteringer i udstillingen forskningsformidling. Montrerne på væggene rundt i rummet fortæller gennem udvalgte genstande om forskellige aspekter ved fundet. I midten af rummet er nogle af pragtgenstandene udstillet meget transparent og uden yderligere beskrivelser. Hensigten med udstillingen var at vise resultater fra forskningen, der sætter fundet $i$ et nyt lys, samt at vise fascinationen af 
60 genstandene. Der blev i planlægningen ikke arbejdet specifikt med mødet med menneskene bag genstandene. ${ }^{6}$

I eksperimentet tilføjede vi ved en montre med fortidens krigeres personlige genstande, en montre med simulerede personlige genstande fra en dansk soldat udstationeret i Helmand provinsen i Afghanistan anno 2008. Montren indeholdt eksempelvis bælte, lighter, cigaretter, billede af ham selv og hans kæreste m.m.

Den forventede effekt med forsøgsopstillingen var at de besøgende, igennem den direkte sammenstilling med sammenlignelige genstande fra forhistoriske krigere og nutidige soldater, ville få en oplevelse af, at de mennesker der kæmpede for 1800 år siden, på mange områder var ligesom de unge mennesker, der drager i krig i dag. Optimalt skulle montren have indeholdt genstande fra en virkelig soldat, der var faldet i Afghanistan. Derved ville opstillingen have haft et endnu større følelsesmæssigt potentiale. Set i lyset af opstillingens eksperimentelle karakter blev der dog valgt at lave en forsøgsopstilling med genstande, der repræsenterede de personlige ting en soldat ville have med sig.

Vi kunne i eksperimentet observere, at de besøgende nu brugte mere end dobbelt så lang tid på montrerne med de personlige genstande, når den ekstra forsøgsmontre var opstillet (2,58 minutter). Det var faktisk også langt mere tid end folk for eksempel brugte hos Grauballemanden (1,54 minutter), der ellers af mange blev omtalt som selve grunden til, at de besøgte museet. Montrerne blev endvidere genstand for diskussioner og italesættelse af netop det faktum, at de personlige genstande fra en forhistorisk kriger og en nutidig soldat er meget ens. Som disse besøgende fortalte:
Når man ser sådan et bæltespænde, det er jo ligesom dem vi har i dag.

Jeg tænker, at der ikke er sket så meget siden.

Igennem interviews med de besøgende kom det frem, at de fleste besøgende var i stand til umiddelbart at aflæse den ekstra montres funktion og sammenhæng med resten af udstillingen og ikke fandt den malplaceret eller forstyrrende. Når børn og voksne var sammen i udstillingen, blev montren med de moderne genstande især flittigt brugt til at reflektere over forskelle mellem dengang og i dag.

Fig. 4. En simpel montre med personligt udstyr fra en nutidig soldat fik de besogende til at bruge i gennemsnit dobbelt så lang tid ved montren med de forhistoriske genstande fra Illerup Adal. Foto: Moesgård Museum.

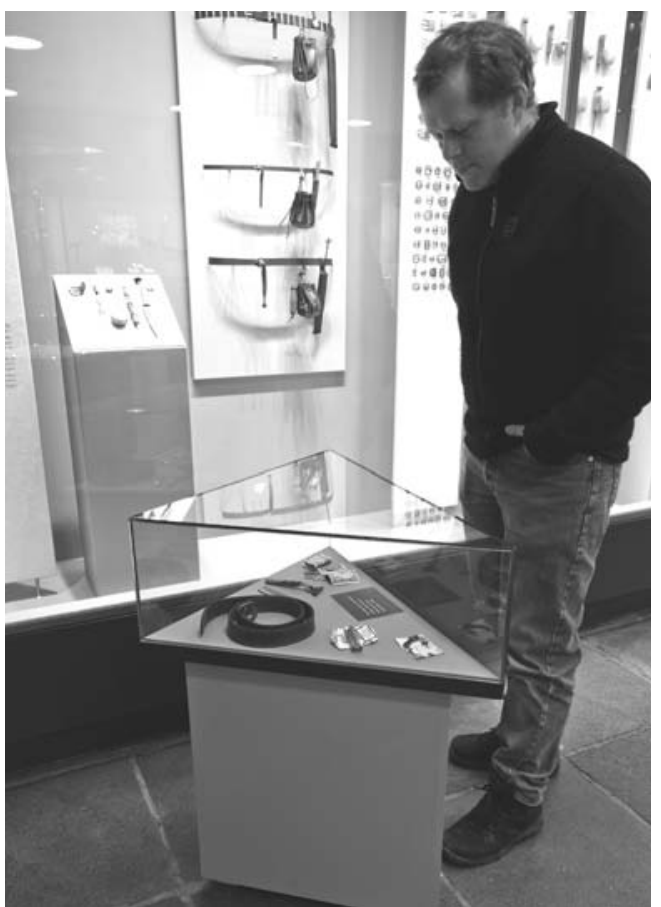


De besøgendes sidestilling af forhistoriske og nutidige genstande skabte på denne måde en intellektuel refleksion. Der var dog ingen indikationer på, at de besøgende, modsat ved Tybrind Vig skeletterne og Grauballemanden, blev følelsesmæssigt berørt af forsøgsinstallationen, hvilket sandsynligvis skyldes at genstande i ekstramontren ganske korrekt blev afkodet som eksempler på en modernes soldats personlige ejendele, og at der ikke var tale om billeder og fortællinger fra en ægte soldats liv og død. Døden blev således ikke umiddelbart opfattet som en del af budskabet.

\section{VIRKER BRUGEN AF FØLELSESMÆSSIGE PÅ- VIRKNINGER I EN UDSTILLING?}

Udgangspunktet for eksperimentet var at finde ud af, hvorvidt det er muligt for museer at skabe forudsætninger for og fremme forskellige følelser hos de besøgende, for herved at påvirke de besøgendes engagement og oplevelse af museet.

Alle tre deleksperimenter synes umiddelbart at skabe et større følelsesmæssigt engagement i udstillingerne, selvom det var meget enkle installationer, der blev anvendt.

Musikken ved Grauballemanden fik de besøgende til at reflektere over såvel hans som deres eget liv. For de besøgende var det nok heller ikke en intellektuel refleksion, der førte til de nye reaktionsmønstre ved mosefundet, men snarere stemningen som den melankolske men melodiske musik gav.

Opstillingen med mor og barn fra $\mathrm{i}$ dag med personerne fra Tybrind Vig, og opstillingen ved Illerup Ådal skulle påvirke de besøgende til at foretage sammenligninger mellem dengang og nu.

Observationerne ved Illerup Ådal var klare. Sammenligningen tiltrak sig opmærksomhed og førte til refleksioner over forskellen mellem tidligere tider og i dag. Fundet fra Illerup Ådal blev mere diskuteret og perspektiveret på grund af det ekstra element.

Opstillingen med mor og barn fra i dag ved Tybrind Vig tiltrak sig derimod ikke meget opmærksomhed og blev i visse tilfælde fundet søgt. Forskellen mellem disse to vidt forskellige receptioner af forsøgsopstillingerne bunder givet vis $i$, at opstillingerne, selv på afstand, appellerer til en intellektuel refleksion, og det således er dette udgangspunkt den besøgende har for at forstå opstillingen.

Den anden opstilling med lydspor ved Tybrind Vig tilførte udstillingen en jeg-fortælling om savn og sorg. I ét registreret tilfælde havde opstillingen det resultat, at den besøgende genvurderede hele udstillingen og fandt den mere relevant og interessant. Det ekstra affektive lag i oplevelsen affødte her, helt i tråd med vores hypotese, et større engagement i og forståelsen af udstillingen.

Vores observationer viste dog også, at det dog langt fra er alle besøgende som fik en oplevelse og reagerede på forsøgene. Ved Grauballemanden havde omkring $2 / 3$ af de interviewede lagt mærke til musikken. Halvdelen af disse gav udtryk for, at musikken havde påvirket deres oplevelse. Det var altså ikke en selvfølge, at opstillingerne påvirkede de besøgende.

Et andet interessant aspekt var, at intet tydede på, at de besøgende var specielt "sårbare" overfor følelsesmæssig påvirkning. Der var ingen der gav udtryk for, at tiltagene var upassende eller at virkemidlerne var for voldsomme. Tværtimod lader det til, at mange overså de emotionelle virkemidler, hvis ikke de var meget eksplicitte.

En lære, der kan drages ud fra denne undersøgelse er, at besøgende ikke umiddelbart finder følelsesmæssige orienterede opstillinger 
62 som fremmedelementer $\mathrm{i}$ et udstillingsforløb, og at opstillinger, når de bliver brugt, kan gå ind og engagere de besøgende og perspektivere museumsoplevelsen. Men for at få et maksimalt udbytte af virkemidlerne er det nødvendigt, at både rumforløb og de enkelte rum er tilrettelagt specifikt i forhold til den sindsstemning de besøgende bør befinde sig i for at være modtagelige over for de forskellige emotionelle virkemidler.

\section{NOTER}

1. Falk \& Dierking 1992.

2. Moesgård Museum er et museum beliggende i Århus med arkæologiske og etnografiske samlinger. Museets mest omtalte fund er Grauballemanden, verdens bedst bevarede moselig dateret til 400-200 f. Kr. I 2008 besøgte 128.806 museet eller deltog i museets aktiviteter.

3. Denne undersøgelse lavede Moesgård Museum i et samarbejde med Niras konsulenterne, der som konsulentfirma blandt andet arbejder med strategiske undersøgelser og bruger- og målgruppeundersøgelser for oplevelsesinstitutioner. Denne undersøgelse blev støttet økonomisk af Kulturarvsstyrelsens pulje til udvikling af museernes formidling.

4. I et interview i forbindelse med undersøgelsen fortalte arkæolog og museumsinspektør Annette Damm om intentionerne bag udstillingen. Annette Damm var en af tilrettelæggerne bag udstillingen, og intentionerne bag udstillingen er også beskrevet i hendes artikel Damm 1985.

5. Hensigten med udstillingen fortalte arkæolog og museumsinspektør Pauline Asingh om i et interview med artiklens forfattere. Pauline Asingh deltog i tilrettelæggelsen af udstillingen. De omfattende arkæologiske undersøgelser af Grauballe- manden, der blev foretaget i 2001 og 2002, er publiceret i Asingh \& Lynnerup 2007.

6. I et interview med artiklens forfattere fortalte professor og arkæolog Jørgen Ilkjær om intentionerne bag udstillingen. Jørgen Ilkjær var med til at udgrave Illerup Ådal fundet og har siden ledet det videnskabelige arbejde med fundet. Jørgen Ilkjær var også med til at tilrettelægge udstillingen "Fjendens ansigt" og skrev i 2000 bogen Illerup Adal - et arkaologisk tryllespejl, der afspejler den struktur udstillingen er opbygget over.

\section{REFERENCER}

Asingh, Pauline \& Niels Lynnerup (red): Grauballe Man. An Iron Age Bog Body Revisited. 2007.

Damm, Annette: Ny stenalderudstilling på Moesgård, i: Dansk tidsskrift for museumsformidling, nr. 8, 1985.

Falk, J.K \& L.D. Dierking: The Museum Experience. 1992.

Ilkjær, Jørgen: Illerup Ådal - et arkaologisk tryllespejl. 2000.

* Martin Brandt Djupdrat

Museumsinspektør og leder af formidlingsafdelingen ved Moesgard Museum

Adresse: Moesgaird Museum

Moesgård Allé 20, DK-8270 Højbjerg

E-mail: moesmbd@hum.au.dk

*Henrik Hatt

Konsulent ved Niras konsulenterne Arhus

Adresse: Niras konsulenterne Arhus

Aboulevarden 80, Postboks 615, DK-8000 Arhus C

E-mail: hha@niraskon.dk 